Neurosurg Focus 19 (5):E9, 2005

\title{
Molecular genetics of meningiomas
}

\author{
Brian T. Ragel, M.D., and Randy L. Jensen, M.D., Ph.D. \\ Department of Neurosurgery, University of Utah; and Huntsman Cancer Institute, Salt Lake City, \\ Utah
}

\begin{abstract}
In this article the authors provide a brief description of the current understanding of meningioma genetics. Chromosome 22 abnormalities, especially in the Neurofibromatosis Type 2 (NF2) gene, have been associated with meningioma development. Loss of heterozygosity of chromosome 22 occurs in approximately $60 \%$ of meningiomas; however, loss of $N F 2$ gene function occurs in only one third of these lesions. This discrepancy supports the theory that a second tumor suppressor gene exists on chromosome 22, and the authors introduce several possible gene candidates, including $B A M 22$, LARGE, INI1, and MN1 genes. Deletions of $1 \mathrm{p}$ have also been shown to correlate with meningioma progression. The genetic similarities and differences among sporadic, NF2-associated, pediatric, and radiation-induced meningiomas are discussed, with the observation that the nonsporadic meningiomas have a higher incidence of multiple chromosomal abnormalities at presentation. Ultimately, a better understanding of the molecular pathways of meningioma tumorigenesis will lead to new, successful treatments.
\end{abstract}

KEY WORDS • meningioma • neurofibromatosis Type 2 gene $・$ merlin • genetics

The study of chromosomal alterations in tumors is an important tool in identifying genes involved in tumorigenesis and tumor progression. Researchers studying the chromosomal abnormalities in meningiomas have identified chromosome 22q, focusing on the NF2 gene, as responsible for the tumorigenesis in roughly one third to one half of meningiomas.

\section{MENINGIOMAS}

Normally slow-growing and benign tumors, meningiomas arise from the central nervous system meninges. ${ }^{6}$ Specialized meningothelial cells called arachnoid cap cells are the source of meningiomas (Fig. 1). These cells are most common within the arachnoid villi but may be present throughout the craniospinal arachnoid space.

\section{Prevalence of the Lesions}

Meningiomas account for approximately $20 \%$ of all primary adult intracranial tumors. They are more common in women (2:1) and generally occur in patients who are between 50 and 60 years old. As shown in Table 1, meningiomas are graded as benign ( 91\% of lesions), atypical (5\%), and anaplastic/malignant (4\%)..$^{28,51}$ The grading of meningiomas takes into account both the tumor subtypes known to have a higher rate of recurrence and the specific histological features that implicate a more aggressive biology. ${ }^{15}$ Although most meningiomas can now be removed

Abbreviations used in this paper: FISH = fluorescence in situ hybridization; $\mathrm{LOH}=$ loss of heterozygosity; NF2 = neurofibromatosis Type 2 . safely, their intrinsic biology is still the main determinant of overall outcome.

\section{Genetic Alterations}

Meningiomas were among the first solid tumors analyzed for genetic abnormalities. Giemsa staining, FISH, comparative genomic hybridization, and spectral karyotyping have been used to elucidate the most common chromosomal abnormalities associated with meningiomas. Abnormalities in the 22q locus have been identified as the most frequent, and approximately $50 \%$ of sporadic meningiomas exhibit a chromosome 22q abnormality. ${ }^{25,26,53,65}$ Meningiomas occurring in the setting of NF2 always exhibit chromosome $22 \mathrm{q}$ abnormalities. Although familial meningiomas are uncommon, they are also usually associated with NF2. ${ }^{13,29}$ Pediatric or radiation-induced meningiomas, on the other hand, tend to have a complex karyotype (that is, multiple chromosomal abnormalities). Chromosome $22 \mathrm{ab}-$ normalities (that is, $\mathrm{LOH}$ or partial deletion of $22 \mathrm{q}$ ) are the most frequent ones in benign, atypical, and anaplastic meningiomas (Figs. 2 and 3A). ${ }^{7,46}$ Chromosome 1 abnormalities have been implicated in tumor progression and highergrade meningiomas. In general, karyotypic abnormalities are more extensive in atypical and anaplastic meningiomas (Fig. 2). ${ }^{4,5,46,63}$ In addition to 1q loss, chromosome aberrations associated with higher-grade meningiomas include those found in 6q, 10p, 10q, 14q, and 18q (Fig. 3B)..$^{14,16,77,80}$ Immunohistochemically, staining for progesterone receptors and the MIB-1 antibody (Ki-67) can aid in differentiating between aggressive tumors (Fig. 2). Progesterone receptor loss correlates with higher meningioma tumor grades, and a higher MIB-1 labeling index has consistently correlated with meningioma recurrence. ${ }^{70}$ 


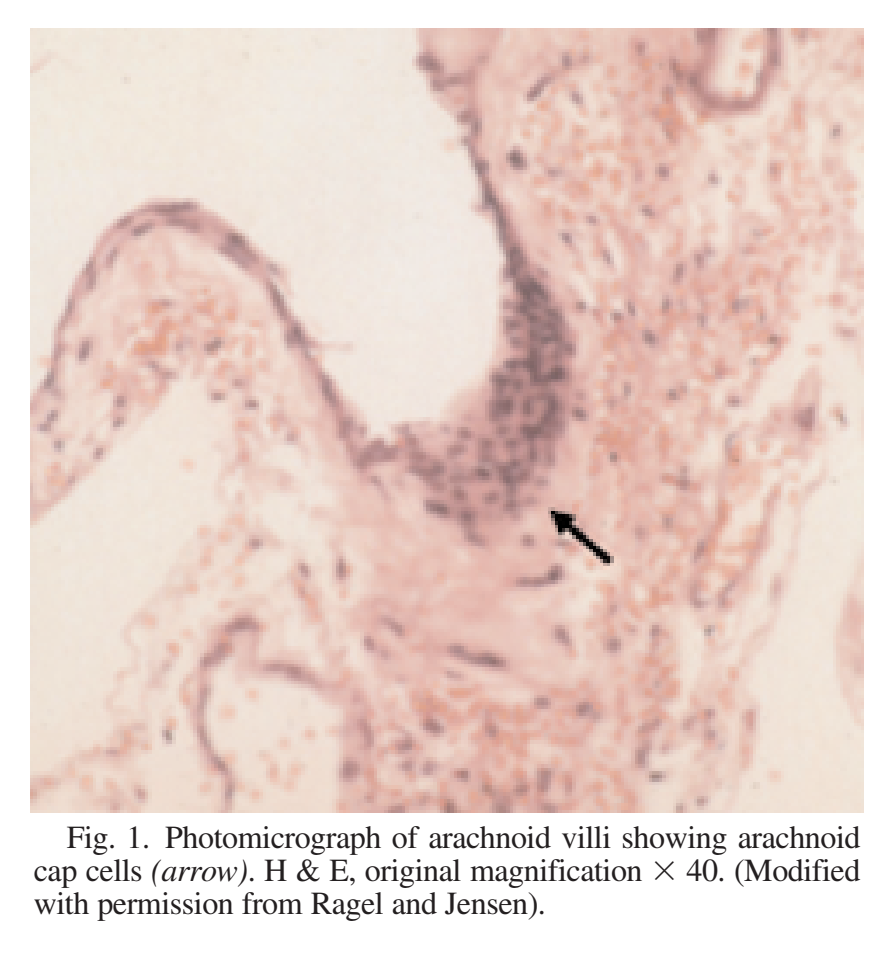

\section{CHROMOSOME 22}

\section{Overview of the Chromosome}

The link between abnormalities in the long arm of chromosome 22 (that is, 22q) and meningiomas was first suspected in patients with NF2. The hallmark of this disease is bilateral acoustic schwannomas as well as meningiomas (occurring in 50\% of patients). ${ }^{27}$ Cytogenetic and molecular studies have culminated in the discovery of the NF2 tumor suppressor gene, located on chromosome 22q12.1, and its protein product (that is, schwannomin or merlin). ${ }^{11,26,42,47}$, 79,89,91 An NF2-associated meningioma is relatively rare, however, because the majority of these lesions occur as isolated, sporadic tumors. Nevertheless, deletions of chromosome 22 are found in all NF2-associated meningiomas, and in 54 to $78 \%$ of sporadic meningiomas. ${ }^{8,19,20,25,46,53,54,56,59,79}$, $89,92-94$

Further analysis of the NF2 gene in sporadic meningiomas reveals that approximately one third to one half of these tumors have an inactivating mutation, often accompanied by loss of the other allele. ${ }^{42,46,73}$ Thus, the frequency of LOH of chromosome 22 exceeds that of NF2 gene abnormalities, with deletion mapping showing interstitial deletions not including the NF2 locus in some meningiomas. ${ }^{73}$ This discrepancy between the higher incidence of chromosome $22 \mathrm{LOH}$ and the lower frequency of NF2 gene mutations has led to the search for a second tumor suppressor gene on $22 \mathrm{q}$, in proximity to but distinct from the $N F 2$ gene. . $20,26,43,44,68,72,73,78$ These studies have resulted in other possible candidates, including the BAM22, LARGE, MN1, and INII genes (Table 2 and Fig. 4). ${ }^{45,65,66,76}$

\section{Chromosome $22 q$}

The NF2 Gene. The NF2 gene codes for the schwanno$\mathrm{min} / \mathrm{merlin}$ protein (also known as moesin-, ezrin-, radixinlike protein), which is a part of the band 4.1 families of cytoskeleton-associated proteins (Table 2). Small insertions or deletions of this gene produce nonsense mutations resulting in a nonfunctional merlin protein..$^{50}$ Loss of the merlin protein results in decreased cell adhesion and tumorigenesis. ${ }^{24,32} \mathrm{~A}$ reduced expression of schwannomin/merlin has been demonstrated in sporadic meningiomas. ${ }^{41}$ Interestingly, meningioma subtypes show differences in their frequency of $N F 2$ gene mutation. The most common meningioma subtypes are fibrous, transitional, and meningothelial (Table 1). Although these World Health Organization Grade I subtypes show no difference in their recurrence rates, there are differences in their rates of NF2 mutations. Fibroblastic and transitional meningiomas exhibit NF2 gene mutations in 70 to $80 \%$ of tumors, whereas the meningothelial subtype shows NF2 mutations only $25 \%$ of the time, suggesting that cytogenetic differences in the tumorigenesis of meningioma subtypes may exist. ${ }^{89}$ In both atypical and anaplastic meningiomas the frequency of NF2 gene mutations is approximately $70 \%$, a frequency closely matching the mutation rate in fibroblastic and transitional meningiomas. ${ }^{41}$ Therefore, NF2 gene mutations are probably involved with tumorigenesis but not tumor progression. Recent in vivo experiments in mice support this theory. Biallelic NF2 inactivation of mouse leptomeningeal cells by using Cre-mediated molecular techniques resulted in the development of meningiomas in approximately one third of mice studied. ${ }^{34}$ This supports the proposition that merlin loss alone is not sufficient for meningioma development.

The BAM22 Gene. The BAM22 gene on chromosome $22 q 12$ is a member of the human $\beta$-adaptin gene family. The $B A M 22$ gene was cloned from a homozygous deletion on one meningioma. ${ }^{65}$ Further analysis revealed that inactivation of the $B A M 22$ gene occurred in nine $(12.7 \%)$ of 71 sporadic meningiomas, with both the BAM22 and $N F 2$ genes affected in two lesions. Although the function of the BAM22 protein is unknown, its similarity to members of the $\beta$-adaptin family indicates that it may have a role in intracellular transport of proteins in the trans-Golgi network.

The LARGE Gene. The LARGE gene was identified in the 22q12.3-q13.1 region as a possible meningioma tumor suppressor gene candidate by applying $\mathrm{LOH}$ studies. Gene cloning of this segment characterized a protein that is structurally similar to members of the $N$-acetylglucosaminyltransferase family. Glycosyltransferase enzymes synthesize glycoprotein and glycosphingolipid sugar chains within different compartments of the Golgi network. Evidence of a role for glycosyltransferase enzymes in tumorigenesis exists (for example, various growth factor receptors appear to be regulated by gangliosides). ${ }^{66}$ Specifically, meningioma

TABLE 1

Pathological classification of meningiomas*

\begin{tabular}{ll}
\hline \hline \multicolumn{1}{c}{ Grade } & \multicolumn{1}{c}{ Meningioma Types } \\
\hline I, typical & $\begin{array}{l}\text { meningothelial, fibrous, transitional, psammomatous, } \\
\text { angiomatous, microcystic, secretory, lymphoplasma- } \\
\text { cyte-rich, metaplastic } \\
\text { chordoid, clear cell } \\
\text { papillary, rhabdoid }\end{array}$ \\
II, atypical & III, anaplastic
\end{tabular}

* Based on World Health Organization classification updates by Louis, et al. 


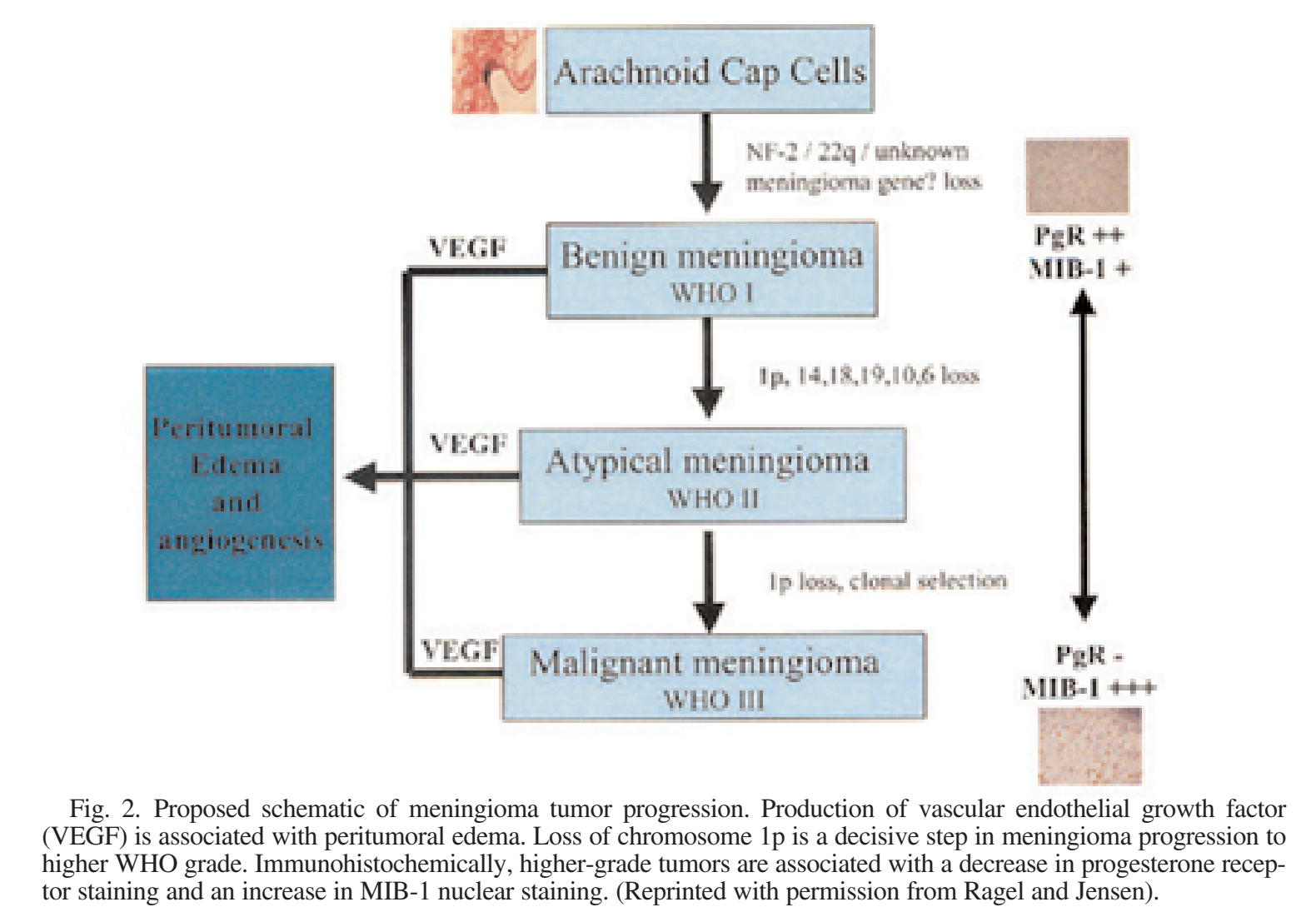

tumor samples can be divided into ganglioside GD3-normal and GD3-rich groups. Furthermore, monosomy 22 correlates with GD3 content, and meningiomas with monosomy 22 show a greater likelihood of recurrence. Therefore, the $L A R G E$ gene is implicated in meningioma tumorigenesis because of its location on chromosome 22, but no evidence exists to implicate this gene directly.

The MN1 Gene. Analysis of a patient with multiple me- ningiomas revealed a missing region on chromosome 22 that encodes for the $M N 1$ gene. ${ }^{45}$ Further analysis of this tumor showed an absence of the MN1 protein with an intact NF2 gene, suggesting a possible role for the MN1 protein in tumor suppression. The function of the MN1 protein is unknown, although based on its amino acid structure, it most likely plays a role in transcription.

The INII Gene. The INII gene is located on chromosome

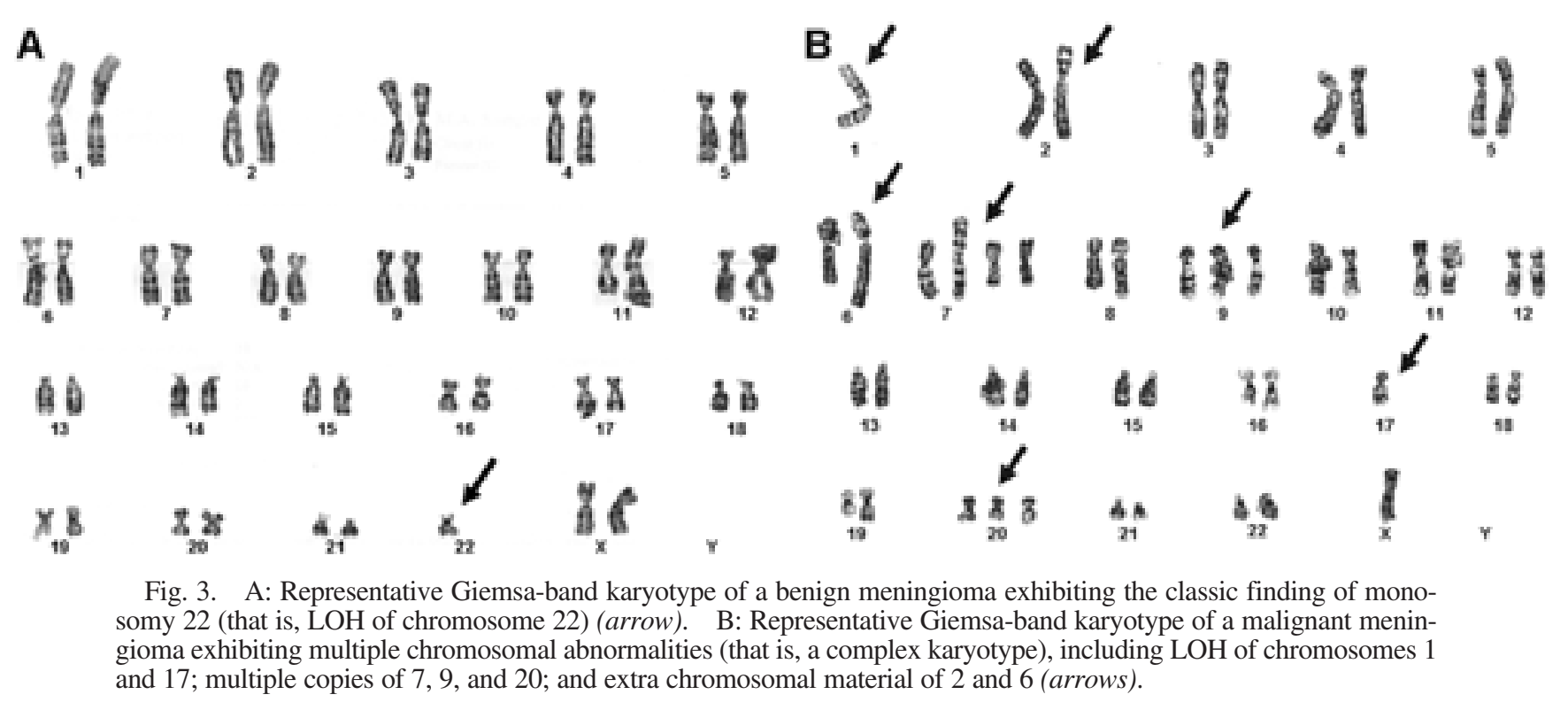


TABLE 2

Meningioma chromosomal abnormalities and their corresponding genes, proteins, and protein function

\begin{tabular}{|c|c|c|c|c|}
\hline Chromosome & Gene(s) & $\operatorname{Protein}(\mathrm{s})$ & Function(s) & Notes \\
\hline $22 \mathrm{q} 12.1$ & $N F 2$ & $\begin{array}{l}\text { merlin/ } \\
\text { schwannomin }\end{array}$ & $\begin{array}{l}\text { regulation of cell } \\
\text { growth \& motility }\end{array}$ & $\begin{array}{l}\text { merlin protein structurally similar to protein } \\
4.1 \text { (DAL-1) superfamily }\end{array}$ \\
\hline $22 q 12$ & $\beta$-adaptin (BAM22) & BAM22 & $\begin{array}{l}\text { intracellular transport } \\
\text { of receptor-ligand } \\
\text { complexes }\end{array}$ & Beta-Adaptin-Meningioma-chromosome 22 \\
\hline $22 \mathrm{q} 12.3-\mathrm{q} 13.1$ & $L A R G E$ & LARGE & $\begin{array}{l}\text { synthesis of glycoprotein } \\
\& \text { glycosphingolipid } \\
\text { sugar chains }\end{array}$ & humanlike acetylglucosaminyltransferase \\
\hline $22 q 11$ & MN1 & MN1 & transcription regulation & \\
\hline $22 \mathrm{q}$ & $\begin{array}{l}\text { INI1 (SMARCB1/ } \\
\text { hSNF5) }\end{array}$ & INI1 & transcription regulation & \\
\hline $1 \mathrm{p}$ & $\begin{array}{l}\operatorname{der}(1)(1 \mathrm{qter} \rightarrow \\
\quad 1 \mathrm{p} 11-22 \mathrm{q} 12 \rightarrow 22 \mathrm{pter})\end{array}$ & unknown & unknown & $\begin{array}{l}\text { 1p13 implicated in radiation-induced } \\
\text { meningiomas }\end{array}$ \\
\hline $9 \mathrm{p} 21$ & $\begin{array}{l}C D K N 2 A\left(p 16^{I N K 4 a}\right) \\
C D K N 2 B\left(p 15^{I N K 4 b}\right) \\
p 14^{A R F}\end{array}$ & & $\begin{array}{l}\text { cell-cycle checkpoint } \\
\text { proteins }\end{array}$ & \\
\hline $18 \mathrm{p} 11.3$ & $D A L-1$ & & cytoskeletal protein & member of 4.1 protein superfamily \\
\hline
\end{tabular}

$22 \mathrm{q}$ and was analyzed for mutations in 126 meningiomas. The analysis showed that four (3\%) of 126 exhibited an identical mutation in exon 9. The function of the INI1 protein is unknown, but its structure suggests that it functions in transcriptional regulation by remodeling chromatin in an adenosine $5^{\prime}$-triphosphate-dependent fashion. ${ }^{76}$

\section{CHROMOSOME 1}

Deletions of the short arm of chromosome 1 are the second most frequent alteration detected on cytogenetic analysis of meningiomas (after chromosome 22 anomalies). ${ }^{9}$ According to FISH studies showing monosomy $1 p$ in $70 \%$ of atypical and almost $100 \%$ of anaplastic meningiomas, this indicates a correlation between loss of chromosome $1 \mathrm{p}$ and meningioma progression. ${ }^{31,55,84,92}$ Loss of $1 \mathrm{p}$ also correlates with tumor recurrence; the rate of recurrence is $30 \%$ with loss of $1 \mathrm{p}$ but only $4.3 \%$ when $1 \mathrm{p}$ is retained. ${ }^{37}$ It is unknown which gene on the $1 \mathrm{p}$ arm results in the clinical effects on tumor, but research has identified alkaline phosphatase as a possible tumor suppressor ${ }^{37,92}$ whose location on chromosome $1 \mathrm{p}(1 \mathrm{p} 34 \rightarrow 1 \mathrm{p} 36.1)$ and loss of function is correlated with higher-grade meningiomas.

\section{OTHER CHROMOSOMAL ABNORMALITIES IDENTIFIED IN MENINGIOMAS}

Many cytogenetic alterations are associated with meningioma progression and typical or anaplastic histology, including the presence of dicentric or ring chromosomes; losses of chromosome arms 1p, 6q, 7, 9p, 10, 14q, 18q, 19, or 20; as well as gains/amplifications of $1 \mathrm{q}, 9 \mathrm{q}, 12 \mathrm{q}, 15 \mathrm{q}$, 17q, or 20q (Figs. 2 and 3A)., $, 14,16,17,35,39,42,58,67,77,80,85,88$ The mechanisms by which these losses and gains aid tumor progression are unknown, although several chromosomes and genes appear to have specific associations with benign, atypical, and anaplastic meningioma grades. Benign meningiomas are more liable to have $14 \mathrm{q}$ deletions. ${ }^{16}$

Approximately two thirds of anaplastic meningiomas exhibit altered cell-cycle checkpoint tumor suppressor genes located on chromosome 9p, including CDKN2A (p16 $\left.6^{I N K 4 a}\right)$, $p 14^{A R F}$, and $C D K N 2 B\left(p 15^{I N K 4 b}\right) .{ }^{14,57}$ Further evidence impli- cating $C D K N 2 A$ deletions in meningioma pathogenesis comes from the significantly shorter survival times of patients with this deletion, compared with those of patients without it. ${ }^{60}$ The membrane-associated 4.1 protein family $D A L-1$ (differently expressed in adenocarcinoma of the lung), located on chromosome 18p11.3, has been suggested as a tumor suppressor. ${ }^{30,61}$

Other rare molecular abnormalities include PTEN gene deletion (10q23), CDKN2C gene deletion (1p32), and RPS $6 K B 1$ gene amplification (17q23). $\cdot^{14,16,17,64}$ No specific tumor suppressor genes associated with meningiomas have been elucidated on chromosome 7. Nevertheless, two growth factors often implicated in meningioma growth and development, epidermal growth factor receptor and insulin-like growth factor-II are located on chromosome $7 .{ }^{12,90}$ Cytogenetic alterations can also include changes in chromosome number. Sixty percent of meningiomas have been found to be hypodiploid, 33\% diploid, $4.5 \%$ hyperdiploid, and $2.5 \%$ hypotriploid. ${ }^{52}$ Complex karyotypes with hypodiploidy, structural rearrangements such as ring chromosomes, dicentrics, double minutes, and association between satellites seem to be associated with aggressive tumor characteristics. ${ }^{48,49}$ Identification of a microsatellite instability phenotype in meningiomas has also been described. ${ }^{69}$

\section{ONCOGENE EXPRESSION IN MENINGIOMAS}

Several studies have shown increased expression of oncogenes in meningioma tumorigenesis. Human meningiomas are marked by enhanced expression of the c-sis and cmyc oncogenes. ${ }^{13,36,82}$ Similarly, the rare Ha-ras and c-mos oncogenes have a higher activation in individuals with intracranial tumors, including meningiomas, than in healthy patients. ${ }^{18,23}$ It has been proposed that the nuclear transcription-regulating genes c-myc and c-fos are normally under the control of tumor suppressor genes, which are lost in meningiomas. ${ }^{22}$ This is supported by the greater than $70 \%$ occurrence of protooncogene messenger RNA expression for c-myc and c-fos in meningiomas. Mutation in the tumor suppressor gene TP53 has been considered a reliable marker for malignant transformation of meningioma, ${ }^{87}$ and the $b c l-2$ protooncogene is also correlated with higher-grade 
meningiomas. ${ }^{1}$ Furthermore, expression of the ROS1 oncogene for tyrosine receptor kinase is common in meningiomas, which indicates that it may play a role in the origin of these tumors. ${ }^{96}$ Although no single oncogene has been directly implicated in meningioma development, it is possible that either one or multiple oncogenes mentioned earlier will contribute to this process.

\section{MENINGIOMA CLONALITY}

Evidence to support the idea that meningiomas are monoclonal in origin is based on X-chromosome inactivation studies and the observation that most meningiomas have only a single NF2 gene mutation. ${ }^{33}$ Polymerase chain reaction evidence suggests, however, that a small number of meningiomas may be polyclonal in origin. ${ }^{97}$ In regard to multiple meningiomas, $\mathrm{X}$-chromosomal analysis and mutational $N F 2$ gene analysis suggest that multiple tumors are monoclonal in origin, ${ }^{40,83}$ supporting dural dissemination through the subarachnoid space. ${ }^{86}$ Nevertheless, approximately $50 \%$ of multiple meningiomas exhibit different $N F 2$ gene mutations, indicating independent tumorigenesis origins. ${ }^{83}$

\section{SPECIAL SITUATION MENINGIOMAS}

\section{The NF2-Associated Meningiomas}

The NF2-associated meningiomas comprise $1 \%$ of all these lesions, ${ }^{62}$ but within the population of patients with NF2, meningiomas are the second most frequent tumor, after vestibular schwannomas. The incidence of meningiomas within this population of patients is between 53 and $83 \% .{ }^{27}$ Higher proliferative indices and histological grades have been reported by some, whereas others have stated that NF2-associated meningiomas are no more aggressive than sporadic tumors. In general, childhood meningiomas are more likely to be associated with NF2, warranting careful examination for NF2 stigmata. ${ }^{63}$ Loss of function of the NF2 gene is generally thought to be the major contributing factor to meningioma development in these patients, as described earlier.

\section{Pediatric Meningiomas}

Pediatric meningiomas represent less than $2 \%$ of all meningiomas and less than $3 \%$ of childhood brain tumors, and occur most commonly in the second decade of life. ${ }^{62}$ Unique features of pediatric meningiomas include a higher incidence of intraventricular locations, cystic changes on imaging, lack of dural attachment, and lack of female predilection. ${ }^{38,62}$ Genetically, when compared with adult sporadic meningiomas, pediatric meningiomas have a higher frequency of NF2 gene mutations as well as $1 p$ and $14 q$ deletions. ${ }^{10,62,81}$ In one study structural abnormalities of chromosome 6 were identified in four of eight cases..$^{10}$ Finally, pediatric meningiomas are reported to display more aggressive characteristics. ${ }^{10,62}$

\section{Radiation-Induced Meningiomas}

A radiation-induced meningioma is one that occurs within a previously irradiated field, is histologically different from the original tumor, appears after a period of time has

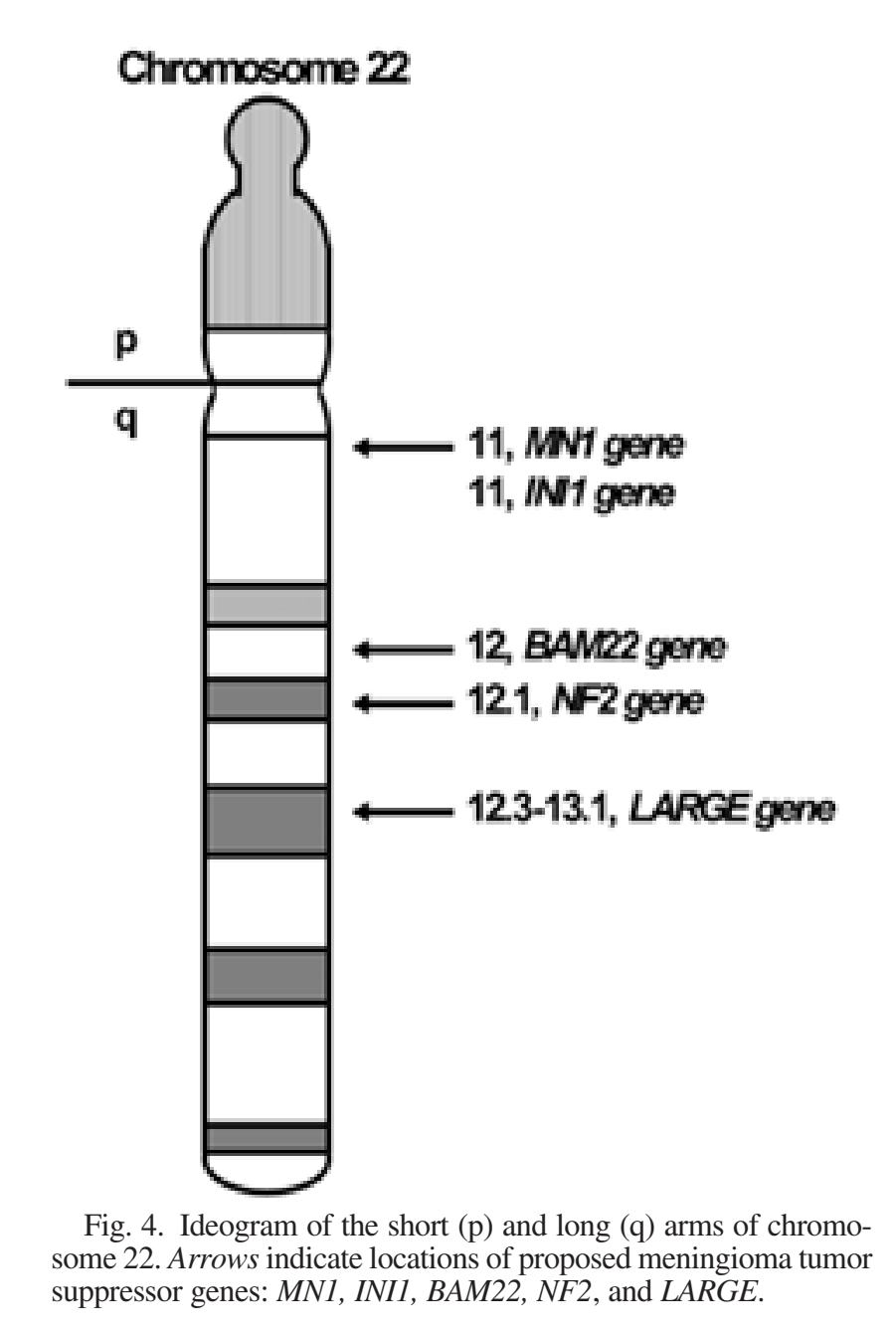

elapsed since irradiation (usually $\geq 5$ years), does not occur in a patient with a family history of phakomatosis, and was not present before radiation therapy was administered..$^{95}$ Compared with sporadic meningiomas, radiation-induced lesions occur in patients of a young age at presentation and have a higher incidence of multiple tumors, a higher malignancy rate, and a higher recurrence rate after treatment with either surgery or radiation. ${ }^{4}$ Although approximately two thirds of sporadic meningiomas occur in women, radiationinduced meningiomas appear to have an equal male/female ratio or even a male predominance. ${ }^{5}$ Most patients with postradiation meningiomas were exposed during childhood (for example, cranial radiation therapy for the treatment of leukemia, lymphoma, or craniopharyngioma). ${ }^{5,74,75,83}$ For example, in Israel during the 1950s, it was common practice to expose children to low-dose radiation to treat scalp tinea capitis, resulting in a significantly increased incidence of meningiomas once these patients became adults. ${ }^{71,74}$ The estimated relative risk for development of a meningioma is 10-fold greater after exposure to low-dose radiation therapy in childhood. ${ }^{74}$ The mean latency period for radiation-induced meningiomas is between 11 and 43 years after exposure. .,95 $^{2}$

Radiation-induced meningiomas usually exhibit a com- 
plex karyotype at presentation (that is, the presence of multiple chromosomal arrangements). ${ }^{5,95}$ Unlike sporadic meningiomas, in radiation-induced lesions $N F 2$ gene inactivation and loss of chromosome 22 are less frequent, with $\mathrm{LOH}$ in chromosome 22 occurring in 29 to $56 \%$ of cases, compared with 43 to $80 \%$ of tumors displaying a loss or translocation of 22q.5.21 The most frequent cytogenetic abnormalities are found on chromosomes 1p (57-89\%), 6q (67\%), and $22(29-58 \%)$ ). ${ }^{595}$ A study of six radiation-induced meningiomas discovered the same chromosomal abnormality on the region of $1 \mathrm{p} 13$, implicating an unknown gene in this region in the pathogenesis of radiation-induced meningiomas. ${ }^{95}$

\section{CONCLUSIONS}

Chromosomal abnormalities have been detected along with meningioma development in numerous studies using Giemsa staining, FISH, comparative genomic hybridization, and spectral karyotyping techniques. The LOH of chromosome 22 occurs in approximately $60 \%$ of meningiomas and loss of NF2 gene function is found in approximately $33 \%$, but abnormalities in other chromosomes and genes have also been implicated. Sporadic, NF2-associated, pediatric, and radiation-induced meningiomas are recognized as potentially having various genetic differences. Further research into how meningioma tumorigenesis and development are affected by the numerous reported irregularities will be necessary to exploit successful new treatments.

\section{Acknowledgment}

We thank Kristin Kraus for her editorial assistance in preparing this paper.

\section{References}

1. Abramovich CM, Prayson RA: Apoptotic activity and bcl-2 immunoreactivity in meningiomas. Association with grade and outcome. Am J Clin Pathol 114:84-92, 2000

2. Akagi K, Kurahashi H, Arita N, et al: Deletion mapping of the long arm of chromosome 22 in human meningiomas. Int J Cancer 60:178-182, 1995

3. Al Saadi A, Latimer F, Madercic M, et al: Cytogenetic studies of human brain tumors and their clinical significance. II. Meningioma. Cancer Genet Cytogenet 26:127-141, 1987

4. Al-Mefty O, Kadri PA, Pravdenkova S, et al: Malignant progression in meningioma: documentation of a series and analysis of cytogenetic findings. J Neurosurg 101:210-218, 2004

5. Al-Mefty O, Topsakal C, Pravdenkova S, et al: Radiation-induced meningiomas: clinical, pathological, cytokinetic, and cytogenetic characteristics. J Neurosurg 100:1002-1013, 2004

6. Al-Rodhan NRF, Laws ER Jr: The history of intracranial meningiomas, in Al-Mefty O (ed): Meningiomas. New York: Raven Press, 1991, pp 1-8

7. Arnoldus EP, Wolters LB, Voormolen JH, et al: Interphase cytogenetics: a new tool for the study of genetic changes in brain tumors. J Neurosurg 76:997-1003, 1992

8. Awad IA, Kalfas I, Hahn JF, et al: Intracranial meningiomas in the aged: surgical outcome in the era of computed tomography. Neurosurgery 24:557-560, 1989

9. Bello MJ, de Campos JM, Kusak ME, et al: Allelic loss at $1 p$ is associated with tumor progression of meningiomas. Genes Chromosomes Cancer 9:296-298, 1994

10. Biegel JA, Parmiter AH, Sutton LN, et al: Abnormalities of chromosome 22 in pediatric meningiomas. Genes Chromosomes Cancer 9:81-87, 1994

11. Bigner SH, Mark J, Bigner DD: Cytogenetics of human brain tumors. Cancer Genet Cytogenet 47:141-154, 1990

12. Bigner SH, Wong AJ, Mark J, et al: Relationship between gene amplification and chromosomal deviations in malignant human gliomas. Cancer Genet Cytogenet 29:165-170, 1987

13. Bolger GB, Stamberg J, Kirsch IR, et al: Chromosome translocation $\mathrm{t}(14 ; 22)$ and oncogene (c-sis) variant in a pedigree with familial meningioma. N Engl J Med 312:564-567, 1985

14. Bostrom J, Meyer-Puttlitz B, Wolter M, et al: Alterations of the tumor suppressor genes $C D K N 2 A\left(p 16^{I N K 4 a}\right), p 14^{A R F}, C D K N 2 B$ $\left(p 15^{I N K 4 b}\right)$, and $C D K N 2 C\left(p 18^{I N K 4 c}\right)$ in atypical and anaplastic meningiomas. Am J Pathol 159:661-669, 2001

15. Burger PC, Scheithauer BW, Vogel FS (eds): Surgical Pathology of the Nervous System and Its Coverings, ed 4. Philadelphia: Churchill Livingstone, 2002

16. Cai DX, Banerjee R, Scheithauer BW, et al: Chromosome 1p and $14 \mathrm{q}$ FISH analysis in clinicopathologic subsets of meningioma: diagnostic and prognostic implications. J Neuropathol Exp Neurol 60:628-636, 2001

17. Cai DX, James CD, Scheithauer BW, et al: PS6K amplification characterizes a small subset of anaplastic meningiomas. Am J Clin Pathol 115:213-218, 2001

18. Carstens C, Messe E, Zang KD, et al: Human KRAS oncogene expression in meningioma. Cancer Lett 43:37-41, 1988

19. Casalone R, Minelli E, Granata P, et al: Pseudodicentric isochromosome(22) in meningiomas. Cancer Genet Cytogenet 45:273-275, 1990

20. Cogen PH, Daneshvar L, Bowcock AM, et al: Loss of heterozygosity for chromosome 22 DNA sequences in human meningioma. Cancer Genet Cytogenet 53:271-277, 1991

21. Comtesse N, Heckel D, Racz A, et al: Five novel immunogenic antigens in meningioma: cloning, expression analysis, and chromosomal mapping. Clin Cancer Res 5:3560-3568, 1999

22. Detta A, Kenny BG, Smith C, et al: Correlation of proto-oncogene expression and proliferation and meningiomas. Neurosurgery 33:1065-1074, 1993

23. Diedrich U, Eckermann O, Schmidtke J: Rare Ha-ras and cmos alleles in patients with intracranial tumors. Neurology 38: 587-589, 1988

24. Dirven CM, Grill J, Lamfers ML, et al: Gene therapy for meningioma: improved gene delivery with targeted adenoviruses. J Neurosurg 97:441-449, 2002

25. Dumanski JP, Carlbom E, Collins VP, et al: Deletion mapping of a locus on human chromosome 22 involved in the oncogenesis of meningioma. Proc Natl Acad Sci U S A 84:9275-9279, 1987

26. Dumanski JP, Rouleau GA, Nordenskjold M, et al: Molecular genetic analysis of chromosome 22 in 81 cases of meningioma. Cancer Res 50:5863-5867, 1990

27. Evans DG, Sainio M, Baser ME: Neurofibromatosis type 2. J Med Genet 37:897-904, 2000

28. Gonzales MF: Classification of brain tumors, in Kaye $\mathrm{AH}$, Laws ER Jr (eds): Brain Tumors, ed 1. Edinburgh: Churchill Livingstone, 1995, p 675

29. Griffin CA, Hruban RH, Long PP, et al: Chromosome abnormalities in meningeal neoplasms: do they correlate with histology? Cancer Genet Cytogenet 78:46-52, 1994

30. Gutmann DH, Donahoe J, Perry A, et al: Loss of DAL-1, a protein 4.1-related tumor suppressor, is an important early event in the pathogenesis of meningiomas. Hum Mol Genet 9: 1495-1500, 2000

31. Henn W, Cremerius U, Heide G, et al: Monosomy 1p is correlated with enhanced in vivo glucose metabolism in meningiomas. Cancer Genet Cytogenet 79:144-148, 1995

32. Ikeda K, Saeki Y, Gonzalez-Agosti C, et al: Inhibition of NF2negative and NF2-positive primary human meningioma cell proliferation by overexpression of merlin due to vector-mediated gene transfer. J Neurosurg 91:85-92, 1999 
33. Jacoby LB, MacCollin M, Louis DN, et al: Exon scanning for mutation of the NF2 gene in schwannomas. Hum Mol Genet 3:413-419, 1994

34. Kalamarides M, Niwa-Kawakita M, Leblois $\mathrm{H}$, et al: $N f 2$ gene inactivation in arachnoidal cells is rate-limiting for meningioma development in the mouse. Genes Dev 16:1060-1065, 2002

35. Katsuyama J, Papenhausen PR, Herz F, et al: Chromosome abnormalities in meningiomas. Cancer Genet Cytogenet 22: 63-68, 1986

36. Kazumoto K, Tamura M, Hoshino H, et al: Enhanced expression of the sis and c-myc oncogenes in human meningiomas. J Neurosurg 72:786-791, 1990

37. Ketter R, Henn W, Niedermayer I, et al: Predictive value of progression-associated chromosomal aberrations for the prognosis of meningiomas: a retrospective study of 198 cases. J Neurosurg 95:601-607, 2001

38. Kleihues P, Louis DN, Scheithauer BW, et al: The WHO classification of tumors of the nervous system. J Neuropathol Exp Neurol 61:215-229, 2002

39. Lamszus K, Kluwe L, Matschke J, et al: Allelic losses at 1p, 9q, $10 \mathrm{q}, 14 \mathrm{q}$, and $22 \mathrm{q}$ in the progression of aggressive meningiomas and undifferentiated meningeal sarcomas. Cancer Genet Cytogenet 110:103-110, 1999

40. Larson JJ, Tew JM Jr, Simon M, et al: Evidence for clonal spread in the development of multiple meningiomas. J Neurosurg 83:705-709, 1995

41. Lee JH, Sundaram V, Stein DJ, et al: Reduced expression of schwannomin/merlin in human sporadic meningiomas. Neurosurgery 40:578-587, 1997

42. Lekanne Deprez RH, Bianchi AB, Groen NA, et al: Frequent NF2 gene transcript mutations in sporadic meningiomas and vestibular schwannomas. Am J Hum Genet 54:1022-1029, 1994

43. Lekanne Deprez RH, Groen NA, Louz D, et al: Constitutional DNA-level aberrations in chromosome 22 in a patient with multiple meningiomas. Genes Chromosomes Cancer 9:124-128, 1994

44. Lekanne Deprez RH, Groen NA, van Biezen NA, et al: A $t(4 ; 22)$ in a meningioma points to the localization of a putative tumor-suppressor gene. Am J Hum Genet 48:783-790, 1991

45. Lekanne Deprez RH, Riegman PH, Groen NA, et al: Cloning and characterization of MN1, a gene from chromosome 22q11, which is disrupted by a balanced translocation in a meningioma. Oncogene 10:1521-1528, 1995

46. Lekanne Deprez RH, Riegman PH, van Drunen E, et al: Cytogenetic, molecular genetic and pathological analyses in 126 meningiomas. J Neuropathol Exp Neurol 54:224-235, 1995

47. Leon SP, Zhu J, Black PM: Genetic aberrations in human brain tumors. Neurosurgery 34:708-722, 1994

48. Lopez-Gines C, Cerda-Nicolas M, Barcia-Salorio JL, et al: Cytogenetical findings of recurrent meningiomas. A study of 10 tumors. Cancer Genet Cytogenet 85:113-117, 1995

49. Lopez-Gines C, Cerda-Nicolas M, Gil-Benso R, et al: Loss of $1 \mathrm{p}$ in recurrent meningiomas: a comparative study in successive recurrences by cytogenetics and fluorescence in situ hybridization. Cancer Genet Cytogenet 125:119-124, 2001

50. Louis DN, Scheithauer BW, Budka H, et al: Meningiomas, in Kleihues P, Cavenee WK (eds): Pathology and Genetics of Tumours of the Nervous System. Lyon: IARC Press, 2000, pp 176-184

51. Mahmood A, Caccamo DV, Tomecek FJ, et al: Atypical and malignant meningiomas: a clinicopathological review. Neurosurgery 33:955-963, 1993

52. Mark J: Chromosomal abnormalities and their specificity in human neoplasms: an assessment of recent observations by banding techniques. Adv Cancer Res 24:165-222, 1977

53. Meese E, Blin N, Zang KD: Loss of heterozygosity and the origin of meningioma. Hum Genet 77:349-351, 1987

54. Merel P, Hoang-Xuan K, Sanson M, et al: Predominant occur- rence of somatic mutations of the NF2 gene in meningiomas and schwannomas. Genes Chromosomes Cancer 13:211-216, 1995

55. Muller P, Henn W, Niedermayer I, et al: Deletion of chromosome $1 \mathrm{p}$ and loss of expression of alkaline phosphatase indicate progression of meningiomas. Clin Cancer Res 5:3569-3577, 1999

56. Ng HK, Lau KM, Tse JY, et al: Combined molecular genetic studies of chromosome $22 \mathrm{q}$ and the neurofibromatosis type 2 gene in central nervous system tumors. Neurosurgery 37:764-773, 1995

57. Ono Y, Ueki K, Joseph JT, et al: Homozygous deletions of the CDKN2/p16 gene in dural hemangiopericytomas. Acta Neuropathol (Berl) 91:221-225, 1996

58. Ozaki S, Nishizaki T, Ito H, et al: Comparative genomic hybridization analysis of genetic alterations associated with malignant progression of meningioma. J Neurooncol 41:167-174, 1999

59. Papi L, De Vitis LR, Vitelli F, et al: Somatic mutations in the neurofibromatosis type 2 gene in sporadic meningiomas. Hum Genet 95:347-351, 1995

60. Perry A, Banerjee R, Lohse CM, et al: A role for chromosome 9 p21 deletions in the malignant progression of meningiomas and the prognosis of anaplastic meningiomas. Brain Pathol 12: 183-190, 2002

61. Perry A, Cai DX, Scheithauer BW, et al: Merlin, DAL-1, and progesterone receptor expression in clinicopathologic subsets of meningioma: a correlative immunohistochemical study of 175 cases. J Neuropathol Exp Neurol 59:872-879, 2000

62. Perry A, Giannini C, Raghavan R, et al: Aggressive phenotypic and genotypic features in pediatric and NF2-associated meningiomas: a clinicopathologic study of 53 cases. J Neuropathol Exp Neurol 60:994-1003, 2001

63. Perry A, Jenkins RB, Dahl RJ, et al: Cytogenetic analysis of aggressive meningiomas: possible diagnostic and prognostic implications. Cancer 77:2567-2573, 1996

64. Peters N, Wellenreuther R, Rollbrocker B, et al: Analysis of the PTEN gene in human meningiomas. Neuropathol Appl Neurobiol 24:3-8, 1998

65. Peyrard M, Fransson I, Xie YG, et al: Characterization of a new member of the human beta-adaptin gene family from chromosome 22q12, a candidate meningioma gene. Hum Mol Genet 3:1393-1399, 1994

66. Peyrard M, Seroussi E, Sandberg-Nordqvist AC, et al: The human LARGE gene from 22q12.3-q13.1 is a new, distinct member of the glycosyltransferase gene family. Proc Natl Acad Sci U S A 96:598-603, 1999

67. Prempree T, Amornmarn R, Faillace WJ, et al: 1;19 translocation in human meningioma. Cancer 71:2306-2311, 1993

68. Pulst SM, Rouleau GA, Marineau C, et al: Familial meningioma is not allelic to neurofibromatosis 2. Neurology 43:2096-2098, 1993

69. Pykett MJ, Murphy M, Harnish PR, et al: Identification of a microsatellite instability phenotype in meningiomas. Cancer Res 54:6340-6343, 1994

70. Ragel B, Jensen R: Pathophysiology of meningiomas. Sem Neurosurg 14:169-186, 2003

71. Ron E, Modan B, Boice JD Jr, et al: Tumors of the brain and nervous system after radiotherapy in childhood. N Engl J Med 319:1033-1039, 1988

72. Ruttledge MH, Sarrazin J, Rangaratnam S, et al: Evidence for the complete inactivation of the NF2 gene in the majority of sporadic meningiomas. Nat Genet 6:180-184, 1994

73. Ruttledge MH, Xie YG, Han FY, et al: Deletions on chromosome 22 in sporadic meningioma. Genes Chromosomes Cancer 10:122-130, 1994

74. Sadetzki S, Flint-Richter P, Ben-Tal T, et al: Radiation-induced meningioma: a descriptive study of 253 cases. J Neurosurg 97: 1078-1082, 2002

75. Salvati M, Cervoni L, Puzzilli F, et al: High-dose radiationinduced meningiomas. Surg Neurol 47:435-442, 1997

76. Schmitz U, Mueller W, Weber M, et al: INI1 mutations in me- 
ningiomas at a potential hotspot in exon 9. Br J Cancer 84: 199-201, 2001

77. Schneider BF, Shashi V, von Kap-herr C, et al: Loss of chromosomes 22 and 14 in the malignant progression of meningiomas. A comparative study of fluorescence in situ hybridization (FISH) and standard cytogenetic analysis. Cancer Genet Cytogenet 85:101-104, 1995

78. Schneider G, Lutz S, Henn W, et al: Search for putative suppressor genes in meningioma: significance of chromosome 22 . Hum Genet 88:579-582, 1992

79. Seizinger BR, de la Monte S, Atkins L, et al: Molecular genetic approach to human meningioma: loss of genes on chromosome 22. Proc Natl Acad Sci U S A 84:5419-5423, 1987

80. Simon M, von Deimling A, Larson JJ, et al: Allelic losses on chromosomes 14,10 , and 1 in atypical and malignant meningiomas: a genetic model of meningioma progression. Cancer Res 55:4696-4701, 1995

81. Slave I, MacCollin MM, Dunn M, et al: Exon scanning for mutations of the NF2 gene in pediatric ependymomas, rhabdoid tumors and meningiomas. Int J Cancer 64:243-247, 1995

82. Smidt M, Kirsch I, Ratner L: Deletion of Alu sequences in the fifth c-sis intron in individuals with meningiomas. J Clin Invest 86:1151-1157, 1990

83. Stangl AP, Wellenreuther R, Lenartz D, et al: Clonality of multiple meningiomas. J Neurosurg 86:853-858, 1997

84. Steudel WI, Feld R, Henn W, et al: Correlation between cytogenetic and clinical findings in 215 human meningiomas. Acta Neurochir Suppl 65:73-76, 1996

85. Vagner Capodano AM, Grisoli F, Gambarelli D, et al: Correlation between cytogenetic and histopathological findings in 75 human meningiomas. Neurosurgery 32:892-900, 1993

86. von Deimling A, Kraus JA, Stangl AP, et al: Evidence for subarachnoid spread in the development of multiple meningiomas. Brain Pathol 5:11-14, 1995

87. Wang GL, Jiang BH, Rue EA, et al: Hypoxia-inducible factor 1 is a basic-helix-loop-helix-PAS heterodimer regulated by cellular $\mathrm{O}_{2}$ tension. Proc Natl Acad Sci U S A 92:5510-5514, 1995

88. Weber RG, Bostrom J, Wolter M, et al: Analysis of genomic al- terations in benign, atypical, and anaplastic meningiomas: toward a genetic model of meningioma progression. Proc Natl Acad Sci U S A 94:14719-14724, 1997

89. Wellenreuther R, Kraus JA, Lenartz D, et al: Analysis of the neurofibromatosis 2 gene reveals molecular variants of meningioma. Am J Pathol 146:827-832, 1995

90. Westphal M, Hansel M, Kunzmann R, et al: Spectrum of karyotypic aberrations in cultured human meningiomas. Cytogenet Cell Genet 52:45-49, 1989

91. Wolff RK, Frazer KA, Jackler RK, et al: Analysis of chromosome 22 deletions in neurofibromatosis type 2-related tumors. Am J Hum Genet 51:478-485, 1992

92. Zang KD: Meningioma: a cytogenetic model of a complex benign human tumor, including data on 394 karyotyped cases. Cytogenet Cell Genet 93:207-220, 2001

93. Zang KD, Singer H: Chromosomal consitution of meningiomas. Nature 216:84-85, 1967

94. Zankl H, Zang KD: Correlations between clinical and cytogenetical data in 180 human meningiomas. Cancer Genet Cytogenet 1:351-356, 1980

95. Zattara-Cannoni H, Roll P, Figarella-Branger D, et al: Cytogenetic study of six cases of radiation-induced meningiomas. Cancer Genet Cytogenet 126:81-84, 2001

96. Zhao JF, Sharma S: Expression of the ROS1 oncogene for tyrosine receptor kinase in adult human meningiomas. Cancer Genet Cytogenet 83:148-154, 1995

97. Zhu J, Frosch MP, Busque L, et al: Analysis of meningiomas by methylation- and transcription-based clonality assays. Cancer Res 55:3865-3872, 1995

Manuscript received September 15, 2005.

Accepted in final form October 12, 2005.

Address reprint requests to: Randy L. Jensen, M.D., Ph.D., Department of Neurosurgery, University of Utah, 30 North 1900 East, Suite 3B409, Salt Lake City, Utah 84132. email: randy.jensen@ hsc.utah.edu. 